\title{
Neuropsychiatric symptoms among welders exposed to neurotoxic metals
}

\author{
Bengt Sjögren, Per Gustavsson, Christer Hogstedt
}

\begin{abstract}
Neuropsychiatric symptoms in 65 welders exposed to aluminium and 217 railroad track welders were studied with the aid of a previously validated questionnaire. Semiquantitative data on exposure to the metals aluminium, chromium, lead, manganese, and nickel were also recorded by questionnaire. Logistic regression was employed to study the relation between exposure and the prevalence of symptoms. Welders exposed to aluminium, lead, or manganese for a long period had significantly more neuropsychiatric symptoms than welders not exposed to these metals. The results indicate that detailed psychometric studies should be performed on welders exposed long term to specific metals as such exposures might affect their nervous system.
\end{abstract}

Aluminium has attracted considerable interest since it was associated with encephalopathy in patients undergoing dialysis. ${ }^{1}$ Patients with severely impaired kidney function cannot eliminate aluminium in the urine, and the metal accumulates in the body as a result of prolonged exposure. Increased concentrations of aluminium in the brain and bone may damage these organs. ${ }^{23}$ Welders exposed to aluminium have significantly higher blood concentrations of aluminium than non-exposed referents, although lower than dialysis patients without signs of encephalopathy. "Welders are sometimes exposed to other neurotoxic metals including lead ${ }^{5}$ and manganese. ${ }^{6}$

The purpose of the present investigation was to study the prevalence of symptoms from the nervous system among welders exposed to aluminium and also to other potentially confounding neurotoxic metals.

Subjects

A group of welders exposed to aluminium was chosen

Department of Occupational Medicine, National Institute of Occupational Health, S-171 84 Solna, and Department of Occupational Medicine, Karolinska Hospital, S-104 01 Stockholm, Sweden

B Sjögren, P Gustavsson, C Hogstedt from companies from which we had previous information on exposure to aluminium welding fumes. ${ }^{7} \mathrm{~A}$ questionnaire, described under Methods was sent to 73 male welders at different places in Sweden who, according to information from their companies, had been exposed to aluminium welding fumes for at least 10 years. Railroad track welders were chosen as a referent group. This group comprised 235 male railroad track welders employed by the Swedish state railways in September 1983. Tables 1 and 2 present the age distribution and the number of years of exposure to welding fumes among the 65 aluminium welders and the 217 railroad track welders who answered the questionnaire.

One third of the railroad track welders had welded high alloy manganese and lead painted steel and such exposures were less common among the welders exposed to aluminium. Thirteen railroad track welders had previously welded aluminium. In the analysis the occurrence of symptoms was studied in relation to data on exposure. Table 3 gives the metal exposures of the total group.

\section{Method}

A questionnaire was constructed to estimate exposure to welding fume from aluminium, chromium,

Table 1 Age distribution among aluminium welders and railroad track welders

\begin{tabular}{|c|c|c|}
\hline $\begin{array}{l}\text { Age of } \\
\text { welders (y) }\end{array}$ & $\begin{array}{l}\text { Aluminium } \\
\text { welders }\left(N_{0}\left(o_{0}\right)\right)\end{array}$ & $\begin{array}{l}\text { Railroad track } \\
\text { welders }(\operatorname{No}(\%))\end{array}$ \\
\hline $\begin{array}{l}20-29 \\
30-39 \\
40-49 \\
50-59 \\
60-69\end{array}$ & $\begin{array}{rr}1 & (2) \\
14 & (21) \\
27 & (42) \\
14 & (21) \\
9 & (14)\end{array}$ & $\begin{array}{ll}22 & (10) \\
87 & (40) \\
49 & (23) \\
46 & (21) \\
13 & (6)\end{array}$ \\
\hline
\end{tabular}

Table 2 Number of years of exposure among aluminium and railroad track welders

\begin{tabular}{|c|c|c|c|}
\hline $\begin{array}{l}\text { Exposure } \\
(y)\end{array}$ & $\begin{array}{l}\text { Aluminium } \\
\text { welders }(N o(\%))\end{array}$ & $\begin{array}{l}\text { Rail } \\
\text { weld }\end{array}$ & $\begin{array}{l}\text { road track } \\
\operatorname{ers}(\operatorname{No}(\%))\end{array}$ \\
\hline $\begin{array}{l}<10 \\
10-19 \\
20-29 \\
30-39\end{array}$ & $\begin{array}{rr}10 & (15) \\
30 & (46) \\
23 & (35) \\
2 & (3)\end{array}$ & $\begin{array}{r}112 \\
64 \\
30 \\
11\end{array}$ & $\begin{array}{r}(52) \\
(29) \\
(14) \\
(5)\end{array}$ \\
\hline
\end{tabular}


Table 3 Metal exposures among welders. Some welders were exposed to more than one metal

\begin{tabular}{|c|c|c|c|}
\hline & \multirow{2}{*}{$\begin{array}{l}\text { Exposed } \\
\text { welders (No) }\end{array}$} & \multicolumn{2}{|c|}{ Exposure time in $100 \mathrm{~h}$} \\
\hline & & Median & Range \\
\hline $\begin{array}{l}\text { Railroad track (iron) } \\
\text { Aluminium } \\
\text { Lead painted } \\
\text { Manganese alloy } \\
\text { Stainless steel }\end{array}$ & $\begin{array}{r}217 \\
78 \\
84 \\
68 \\
63\end{array}$ & $\begin{array}{r}71 \\
141 \\
20 \\
20 \\
24\end{array}$ & $\begin{array}{l}3-440 \\
2-600 \\
0 \cdot 5-171 \\
0 \cdot 5-361 \\
0 \cdot 5-275\end{array}$ \\
\hline
\end{tabular}

lead, manganese, and nickel. The welders reported number of hours a day and number of years of exposure. Questions concerning symptoms from the nervous system were based on questionnaire 16 (Q16) ${ }^{8}$ which contained questions on disturbances of memory and concentration, affective changes, and symptoms from the vegetative nervous system. This questionnaire was developed as a screening instrument for symptoms among workers exposed to solvents and has also been used in several epidemiological studies.

The questionnaire was sent to all 308 welders in November 1985 and $92^{\circ}{ }_{0}$ answered after reminders. Three of the non-responders were working abroad. Twenty three per cent of the welders did not answer the questionnaire completely. These welders, who were evenly distributed between the two groups, were further interviewed by mail or by telephone.

The number of positive answers in Q16 had a skew distribution (table 4). There is no established limit for the number of positive answers to discriminate between health and ill health. The outcome was, therefore, dichotomised according to the median number of symptoms in a "healthy" group with less than three positive answers and an "unhealthy" group with three or more positive answers.

The relation between exposure, age, and occurrence of neuropsychiatric symptoms assessed by the Q16 was analysed by unconditional logistic regression. ${ }^{910}$ The variables were included as follows:

$$
\text { Logit } P(X)=a+b_{1} x_{1}+b_{2} x_{2}+\ldots b_{15} x_{15}
$$

where $P(X)$ is the probability of having three or more symptoms in Q16 and $x_{1}-x_{15}$ are all included variables (table 5). The total time of exposure to each metal was calculated for all subjects. The total number of exposed hours was calculated in the following way:

Number of exposed hours per day

$$
8 \text { number of exposed years }
$$

The number of working hours a day was eight. The mean number of working hours a year was 1570 at the end of the 1970s and during the 1980s when absence was excluded. Previously the total number of working hours a day as well as the working hours a year were higher.
Table 4 Distribution of number of positive answers in questionnnaire $Q 16$ among all welders

\begin{tabular}{lcc}
\hline No of positive answers & \multicolumn{2}{c}{ No of welders $\left({ }^{\circ}{ }_{o}\right)$} \\
\hline 0 & 67 & $(24)$ \\
1 & 46 & $(16)$ \\
2 & 22 & $(8)$ \\
3 & 27 & $(10)$ \\
4 & 22 & $(8)$ \\
5 & 24 & $(9)$ \\
6 & 21 & $(7)$ \\
7 & 12 & $(4)$ \\
8 & 13 & $(5)$ \\
9 & 9 & $(3)$ \\
10 & 6 & $(2)$ \\
11 & 7 & $(2)$ \\
12 & 5 & $(2)$ \\
13 & -1 & $(-)$ \\
14 & 1 & $(0)$ \\
\hline
\end{tabular}

Table 5 Odds ratios corresponding to three or more symptoms in Q16 among welders of different ages and exposed to different metals. Odds ratio for "non-exposed"

\begin{tabular}{|c|c|c|c|}
\hline Variable & $\begin{array}{l}\text { Variable in } \\
\text { equation }\end{array}$ & $O R$ & $95^{\circ}{ }_{0} C I$ \\
\hline $\begin{array}{c}\text { Age (y): } \\
20-29 \\
30-39 \\
40-49 \\
50\end{array}$ & $\begin{array}{l}x_{1} \\
x_{2} \\
x_{3}\end{array}$ & $\begin{array}{l}1.0 \\
1.73 \\
1.05 \\
1.49\end{array}$ & $\begin{array}{l}0 \cdot 66-4 \cdot 58 \\
0 \cdot 38-2.94 \\
0.54-4 \cdot 11\end{array}$ \\
\hline $\begin{array}{r}\text { Aluminium (h): } \\
200-7875 \\
7875-20500 \\
20500-60000\end{array}$ & $\begin{array}{l}x_{4} \\
x_{5} \\
x_{6}\end{array}$ & $\begin{array}{l}0.98 \\
2 \cdot 38 \\
2 \cdot 79\end{array}$ & $\begin{array}{l}0.36-2 \cdot 66 \\
0.99-5 \cdot 72 \\
1.08-7 \cdot 21\end{array}$ \\
\hline $\begin{array}{c}\text { Chromium and } \mathrm{r} \\
50-1125 \\
1125-3938 \\
3938-27480\end{array}$ & $\begin{array}{l}: \\
\mathbf{x}_{7} \\
\mathbf{x}_{8} \\
\mathbf{x}_{9}\end{array}$ & $\begin{array}{l}0.78 \\
1.25 \\
1 \cdot 17\end{array}$ & $\begin{array}{l}0 \cdot 26-2 \cdot 36 \\
0 \cdot 49-3 \cdot 19 \\
0 \cdot 41-3 \cdot 33\end{array}$ \\
\hline $\begin{array}{l}\text { Lead }(h): \\
50-1125 \\
1125-3000 \\
3000-17080\end{array}$ & $\begin{array}{l}x_{10} \\
x_{11} \\
x_{12}\end{array}$ & $\begin{array}{l}1.51 \\
0.95 \\
3.52\end{array}$ & $\begin{array}{l}0 \cdot 59-3 \cdot 85 \\
0 \cdot 41-2 \cdot 20 \\
1 \cdot 26-9 \cdot 84\end{array}$ \\
\hline $\begin{array}{c}\text { Manganese (h): } \\
50-1000 \\
1000-3250 \\
3250-36110\end{array}$ & $\begin{array}{l}\mathbf{x}_{13} \\
\mathbf{x}_{14} \\
\mathbf{x}_{15}\end{array}$ & $\begin{array}{l}0 \cdot 73 \\
2 \cdot 34 \\
6 \cdot 25\end{array}$ & $\begin{array}{l}0.26-2 \cdot 07 \\
0.88-6.24 \\
1.95-20 \cdot 0\end{array}$ \\
\hline
\end{tabular}
welders between 20 and 29 years of age is by definition 1.0

The cumulated exposure to each of the metals was categorised on a quantitative scale. Category 0 indicated that exposure was lacking for the metal of interest. Category 1 contained low exposed, category 2 medium exposed, and category 3 high exposed welders. Each category of exposure was formed to contain about the same number of subjects, and table 5 gives the limits of the categories. The categories of exposure were introduced as factors in the model.

Odds ratios (ORs) were obtained from the regression equation. The ORs were based on the prevalence of symptoms in this cross sectional study. The prevalence $O R$ is a good approximation of the incidence rate ratio if the duration of symptoms is the same among the exposed and the non-exposed workers. ${ }^{11}$ 


\section{Results}

The number of positive answers did not follow a normal distribution but was skewed towards a lack of positive response (table 4).

All variables were included in the analysis (table 5). Welders with long term exposure to aluminium, lead, or manganese showed an increased risk of having three or more symptoms, whereas welders exposed to chromium and nickel did not. Age had a minor influence on the number of positive answers.

Each question in the questionnaire was also analysed in relation to exposure. Two symptoms were related to exposure to aluminium. They were based on the questions "Do you often have problems with concentrating?" $(\mathrm{OR}=2.34,95 \% \mathrm{CI}=$ $1 \cdot 15-4 \cdot 76)$ and "Do you often feel depressed without any particular reason?" $(\mathrm{OR}=2 \cdot 75,95 \% \mathrm{CI}=$ 1.16-6.53). Three symptoms were related to exposure to lead painted steel based on answers to the questions "Have your relatives told you that you have a short memory?" $(\mathrm{OR}=1 \cdot 87,95 \% \mathrm{CI}=1 \cdot 03$ 3.37). "Do you often have to go back and check things you have done, such as turned off the stove, locked the door, etc?"' (OR $=2 \cdot 04,95 \% \mathrm{CI}=1 \cdot 13-3 \cdot 69)$. "Do you have a headache at least once a week?" (OR $\left.=1.95,95^{\circ}{ }_{0} \mathrm{CI}=1 \cdot 00-3 \cdot 81\right)$. One question was related to exposure to high alloy manganese steelnamely, "Do you often have painful tingling in some part of your body?" $(\mathrm{OR}=2 \cdot 03,95 \% \mathrm{CI}=1 \cdot 11-$ $3 \cdot 71)$.

\section{Discussion}

In this study welders with long term exposure to aluminium, lead, or manganese reported an increased number of symptoms from the nervous system. These results are discussed in relation to previous knowledge and potential sources of error.

\section{ALUMINIUM}

Welders reporting exposure to aluminium fumes for more than 20000 hours, corresponding to about 13 years of full time exposure, had a doubled risk of answering Q16 with three or more positive answers. These results support the hypothesis that exposure to aluminium may be an occupational hazard. In an earlier study we found that aluminium welders exposed for about 20 years had 100 times higher urinary concentrations of aluminium compared with industrially non-exposed workers ${ }^{12}$ and long-term exposed welders have an estimated half time of urinary aluminium of six months or longer. ${ }^{13}$ As aluminium is a neurotoxic metal, it seems biologically plausible that high and long term occupational exposure to welding fume containing aluminium may have neurotoxic effects.

CHROMIUM AND NICKEL

Stainless steel contains chromium and nickel but neither is known to affect the nervous system ${ }^{14} 15$ and these exposures did not relate to any symptoms in the questionnaire. This result might be regarded as support for the validity of the positive findings; a general tendency to over-report symptoms would not have been selective to specific metals.

\section{LEAD}

Lead is a well known neurotoxic metal. ${ }^{5}$ Welders exposed for more than two years full time had a trebled risk of answering Q16 with three or more positive answers. Data regarding concentrations of lead are unfortunately lacking for this group of welders. Other workers exposed to lead had an increased number of neuropsychiatric symptoms as well as decreased performances in psychometric tests. $^{16}$

\section{MANGANESE}

Manganese is known to have neurotoxic effects ${ }^{6}$ and welders exposed full time for more than two years had a six times higher risk of answering Q16 with three or more positive answers. During railroad track welding two manganese electrodes are used (OK 86.08 and $O K \quad 86.28$ ) and the smoke from these electrodes contains $20-25 \%$ manganese according to the manufacturer. In a group of welders exposed to 1-4 mg of manganese per $\mathrm{m}^{3}$ for a mean period of 16 years a relation was found between the duration of exposure and an integrated measure of reaction time. $^{17}$

\section{POTENTIAL SOURCES OF ERROR}

The group of welders exposed to aluminium was chosen from companies investigated earlier in a national survey of exposure to welding fumes. ${ }^{18}$ All welders exposed to aluminium fumes long term in the country were not included but it seems unlikely that any systematic error would have been introduced by the selection.

The time the arc is lit as a percentage of the total working day is defined as the arc time. The arc time is about $5 \%$ when overlaying rail, an operation sometimes associated with exposure to manganese. For mold welding of rails the arc time is about $12 \%$ and for metal arc welding in workshops the arc time is about $20 \% .{ }^{18}$ In this investigation more than half of the railroad track welders stated that they welded for four hours or more a day. It is obvious that the stated welding time is not equivalent to the arc time. This discrepancy probably does not, however, invalidate the use of such data for a rough categorisation of exposure.

The questionnaire did not contain questions concerning other potentially toxic agents that might effect the nervous system, such as alcohol and organic solvents. It seems, however, unlikely that such exposures should differ considerably between the 
groups. The welders were probably comparable concerning education, social background, and occupational background irrespective of welded material. Wages and security of employment may vary but it seems unlikely that such factors could explain the differences found.

\section{VALIDITY OF THE QUESTIONNAIRE}

Questionnaire 16 has not yet been fully validated against other means of measuring early disorders of the central nervous system. A higher proportion of positive answers, however, has been related to decreased psychometric performance in groups exposed to lead ${ }^{16}$ and organic solvents. ${ }^{819}$ Groups exposed to organic solvents reported an increased number of symptoms in a dose response fashion..$^{8} 1920$ The simple addition of symptoms arising from different nervous functions has been criticised ${ }^{21}$ but the extensive experience of this mode of evaluation indicates that the technique is valid for early detection of neuropsychiatric effects.

\section{Conclusion}

Welders exposed to aluminium, lead, or manganese for a long period had more neuropsychiatric symptoms than welders not exposed to these metals. Such results might be regarded as a warning that prolonged exposure to specific metal welding fumes could affect the central nervous system. Clinical and psychometric studies of long term exposed welders should be carried out to verify or refute these results.

We acknowledge the advice of Lars Hedström from our department and Rolf Sundberg, Institute of Insurance and Mathematical Statistics, University of Stockholm. We appreciate the processing of data by Evy Fellenius and Annika Gustavsson. We also thank Anders Ahlbom, Department of Epidemiology, Institute of Environmental Medicine, Karolinska Institute, for comments.

Requests for reprints to: Bengt Sjögren, Department of Occupational Medicine, National Institute of Occupational Health, S-171 84 Solna, Sweden.
1 Alfrey AC, LeGendre GR, Kaehny WD. The dialysis encephalopathy syndrome, possible aluminium intoxication. N Engl J Med 1976;294:184-8.

2 Elinder CG, Sjögren B. Aluminium. In: Friberg L, Nordberg GF, Vouk VB, eds. Handbook on the toxicology of metals. Vol II. Amsterdam: Elsevier Science Publishers, 1986:1-25.

3 Schreeder MT, Favero MS, Hughes JR, Petersen NJ, Bennett PH, Maynard JE. Dialysis encephalopathy and aluminium exposure: an epidemiologic analysis. J Chronic Dis 1983;36: 581-93.

4 Sjögren B, Lundberg I, Lidums V. Aluminium in the blood and urine of industrially exposed workers. Br J Ind Med 1983; 40:301-4.

5 Tsuchiya K. Lead. In: Friberg L, Nordberg GF, Vouk VB, eds. Handbook on the toxicology of metals. Vol II. Amsterdam: Elsevier Science Publishers, 1986:298-353.

6 Saric M. Manganese. In: Friberg L, Nordberg GF, Vouk VB, eds. Handbook on the toxicology of metals. Vol II. Amsterdam: Elsevier Science Publishers, 1986:354-86.

7 Sjögren B, Ulfvarson U. Respiratory symptoms and pulmonary function among welders working with aluminium, stainless steel and railroad tracks. Scand J Work Environ Health 1985 ; 11:27-32.

8 Hogstedt C, Andersson K, Hane M. A questionnaire approach to the monitoring of early disturbances in central nervous functions. In: Aitio A, Rühimaki V, Vainio H, eds. Biologicul monitoring and surveillance of workers exposed to chemicals. Washington: Hemisphere Publishing Corporation, 1984: 275-87.

9 Breslow NE, Day NE. Statistical methods in cancer research. Vol 1. The analysis of case-control studies. Lyon: International Agency for Research on Cancer, 1980. (IARC sci publ No 32.)

10 Schlesselman JJ. Case-control studies. Design, conduct, analysis. Oxford: Oxford University Press, 1982.

11 Kleinbaum DG, Kupper LL, Morgenstern H. Epidemiologic research. New York: Van Nostrand Reinhold, 1982.

12 Sjögren B, Lidums V, Hảkansson M, Hedström L. Exposure and urinary excretion of aluminium during welding. Scand $J$ Work Environ Health 1985;11:39-43.

13 Sjögren B, Elinder CG, Lidums V, Chang G. Uptake and urinary excretion of aluminium among welders. Int Arch Occup Environ Health 1988;60:77-9.

14 Langard S, Norseth T. Chromium. In: Friberg L, Nordberg GF, Vouk VB, eds. Handbook on the toxicology of metals. Vol II. Amsterdam: Elsevier Science Publishers BV, 1986: 185-210.

15 Norseth T. Nickel. In: Friberg L, Nordberg GF, Vouk VB, eds. Handbook on the toxicology of metals. Vol II. Amsterdam: Elsevier Science Publishers BV, 1986:462-81.

16 Hogstedt C, Hane M, Agrell A, Bodin L. Neuropsychological test results and symptoms among workers with well-defined long-term exposure to lead. Br J Ind Med 1983;40:99-105.

17 Siegl P, Bergert K-D. Eine frudiagnostische Uberwachungsmethode bei Manganexposition. $Z$ Gesamte Hyg 1982;28: 524-6.

18 Ulfvarson U. Survey of air contaminants from welding. Scand $J$ Work Environ Health 1981;7(suppl 2):13.

19 Fidler AT, Baker EL, Letz RE. Neurobehavioural effects of occupational exposure to organic solvents among construction painters. Br J Ind Med 1987;44:292-308.

20 Flodin U, Ekberg K, Andersson L. Neuropsychiatric effects of low exposure to styrene. $\mathrm{Br} J$ Ind $\mathrm{Med}$ 1989;46:805-8.

21 Olsen J, Sabroe S. Screening for neuropsychiatric dysfunction. Scand J Soc Med 1984;12:55-63.

Accepted 30 April 1990 